\title{
Albert the Great on the Subject of Metaphysics and Demonstrating the Existence of God
}

\author{
TIMOTHY B. NOONE
}

In his comprehensive study of Thomas Aquinas's Sententia super Metaphysicam, James Doig introduces Albert the Great as one of the commentators whose interpretation of Aristotle's Metaphysics Thomas intended to challenge. In particular, Doig alleges that Albert's understanding of the formal object (or, in other terminology, the subject) of metaphysics is heavily indebted to the writings of Averroës, although the modern scholar acknowledges that Albert does not follow the Averroistic interpretation in all respects. ${ }^{1}$ Furthermore, Doig contends that Albert's own Metaphysica, following Averroës's schema of metaphysical knowledge, contains no proof of the existence of God as the cause of being but simply relies on the proof of God as the cause of motion, as was developed in Aristotle's Physics. ${ }^{2}$

1. James C. Doig, Aquinas on Metaphysics: A Historico-Doctrinal Study of the Commentary on the Metaphysics (The Hague: Martinus Nijhoff, 1972), pp. 53-54, 125-152. The present paper originated as part of the author's licentiate thesis at the Pontifical Institute of Mediaeval Studies, Toronto. I would like to dedicate the paper to the late James A. Weisheipl, who directed the thesis, even as I acknowledge that he would have disagreed heartily with its conclusions.

2. For example, Doig, Aquinas on Metaphysics, pp. 202, 204. 
In marked contrast to Doig's interpretation, Albert Zimmermann, in a monograph devoted to medieval conceptions of the subject of metaphysics, proposes that the main historical influence on Albert's teaching on the subject of metaphysics is not Averroës but Avicenna. ${ }^{3}$ In light of these conflicting interpretations of Albert's position on the subject of metaphysics and the relation to metaphysics of proofs for God's existence, the present paper has a twofold purpose: first, to show that Albert's position on the subject of metaphysics, although original in many regards, is inspired by Avicenna rather than Averroës; and, second, to provide textual evidence that Albert maintains that there is a proof for the existence of God as a causa essendi, and not merely a causa motus, in his Metaphysica.

The immediate sources of inspiration for medieval discussions of the subject of metaphysics were the writings of Avicenna and Averroës, who had sketched out divergent theories of metaphysical knowledge. ${ }^{4}$ Avicenna, applying to metaphysics the model of scientific knowledge that had been advocated by Aristotle in his Posterior Analytics, argued that the subject of metaphysics was being qua being, the being common to substance, accidents, and God. Yet Averroës found the Avicennian account of the subject of metaphysics to be both un-Aristotelian in inspiration and unsound in approach. Instead, Averroës contended that the proper subjects of metaphysics were the separate entities that functioned as the first and primary instances of substance or true being. Since the first task of this paper is to assess

3. Albert Zimmermann, Ontologie oder Metaphysik?: Die Diskussion über den Gegenstand der Metaphysik im 13, und 14. Jahrhundert, Studien und Texte zur Geistesgeschichte des Mittelalters 8 (Leiden and Cologne: E. J. Brill, 1965), p. 149. Doig seems to have been unaware of Zimmermann's interpretation. In another study, Zimmermann has argued that, although "Averroists" such as Siger of Brabant looked to Albert's writings for guidance in interpreting Aristotle and in distinguishing philosophical from theological knowledge, Albert by no means either shared their tendency to glorify Aristotle or embraced their distinctive doctrinal tenets. See Zimmermann, "Albertus Magnus und der lateinische Averroismus," in Albertus Magnus: Doctor Universalis, 1280-1980, ed. Gerbert Meyer and Albert Zimmermann (Mainz: Matthias-Grünewald, 1980), pp. 465-493.

4. On the background for the medieval discussions of metaphysics as a science, see Doig, Aquinas on Metaphysics, pp. 23-46; Zimmermann, Ontologie oder Metaphysik? pp. 85-119; Stephen F. Brown, "Avicenna and the Unity of the Concept of Being," Franciscan Studies 25 (1965): 117-150. 
whether Albert the Great's account of the subject of metaphysics owes more to Avicenna or Averroës, we should acquaint ourselves, however briefly, with some of the finer points in each Islamic philosopher's position and the texts in which their theories were made available to Latin readers.

\section{THE ISLAMIC BACKGROUND}

\section{AVICENNA}

After discussing the general division of theoretical philosophy into its three branches of natural philosophy, mathematics, and divine science, Avicenna proceeds, in his De prima philosophia, to analyze the subject of divine science, or metaphysics. Although the phrase that he uses to describe metaphysics, "divine science," might lead one to believe that God would be the subject of metaphysics for Avicenna, in fact he explicitly rejects that possibility. His reasoning for doing so is concisely stated and shows the extent to which Avicenna had mastered the scientific methodology of Aristotle's Posterior Analytics.

For Aristotle, every science treats a subject whose existence is obvious but whose precise properties and attributes are unknown. Proceeding from the principles of the subject of the science and other generally understood principles as related to the subject, a given science shows which properties and attributes belong to the subject as such through reasoned argument or demonstration. ${ }^{5}$ In light of such considerations, Avicenna points out, one and the same thing cannot both be the subject of a science and yet be sought (quaesitum) by the science, namely, be the conclusion of a demonstration, because this would entail that the same thing be presupposed and proved in the same science. Accordingly, if God is sought in metaphysics, God cannot be the subject of metaphysics. 6

\section{Aristotle Posterior Analytics 1.10.76a31-76b23.}

6. Avicenna Liber de philosophia prima sive scientia divina 1.1.1, as in Avicenna Latinus 4 (Leiden; Louvain: E. J. Brill; E. Peeters, 1977), p. 4, lines 57-65. Hereafter Avicenna's work will be cited simply as Metaph., and this edition will be cited in parentheses by volume, page, and line numbers. 
How, it might be objected, do we know that God is sought in metaphysics? Avicenna anticipates such an objection by taking up and then examining the consequences of the hypothesis that God is not sought in metaphysics. If God were not sought in metaphysics, then either God's existence would be conceded for metaphysics, while established in another science, or God's existence would be granted in metaphysics and not established in another science. The former alternative cannot be true, because no other science even takes up the question whether God exists. In short, we know that God's existence is not sought in any other science by a type of induction, a simple recounting of the questions taken up in other branches of philosophy ("et tu scies hoc parva inspectione ex his quae multotiens inculcamus"), since the branches of philosophy are believed to be exhaustive of knowledge. The latter alternative also cannot be true, for it would imply either that God's existence were immediately known (manifestum per se) or were completely beyond human ken (desparatum per se), both of which Avicenna thinks are clearly false. God's existence cannot be immediately known, if, as is clearly so, some people are unaware of God's existence. Nor can God's existence be beyond human ken, if we perceive signs of God's existence (signa habemus de eo).?

Since every alternative underlying the hypothesis that God is not sought in metaphysics has proved to be false, the hypothesis itself must be false. Avicenna concludes that God is indeed sought (quaesitum) in metaphysics and, for that reason, is not the subject of metaphysics. ${ }^{8}$

Yet to state that God is not the subject of metaphysics is not to say what the subject of metaphysics is, as Avicenna well knows. Hence Avicenna devotes a number of pages to considering an alternative subject for metaphysics, the ultimate causes, and to exploring dialectically what requirements a candidate for the subject of metaphysics must meet. The possibility that the ultimate material, formal, efficient, and final causes, either singly taken or in combination, constitute the subject of metaphysics is rejected because of another requirement for scientific knowledge laid down in the Posterior Analytics: the subject of a science must be the common subject of investigation for every

7. Avicenna Metaph. 1.1.1 (4:4.64-5.79).

8. Avicenna Metaph. 1.1.1 (4:5.80-81). 
part of the science. ${ }^{9}$ But, Avicenna reasons, metaphysics investigates matters such as the universal and the particular, potency and act, as well as the possible and the necessary, none of which fall under the notion of causality. ${ }^{10}$ Thus metaphysics cannot have as its subject the ultimate causes, whether these be taken singly or collectively. In exploring the logical requirements for the subject of metaphysics, moreover, Avicenna notes that the subject will have to be comprehensive enough to permit the metaphysician to study such divergent topics as the nature of body (in the sense of its ontological structure), the nature of substance, and the status of mathematicals, since no other science treats such matters, despite their manifest importance. ${ }^{11}$

After these preliminary observations, Avicenna urges the conclusion that only being insofar as it is being is sufficiently universal and comprehensive to serve as the subject of metaphysics. Only being can function as something common to accidents and substance; only being can be the subject of discourse in discussions of unity and plurality, sameness and otherness. 12

For our purposes, three things must be remembered from Avicenna's account of metaphysical knowledge: (1) He firmly and forthrightly rejects the opinion that God is the subject of metaphysics. (2) He posits being as common both to substance and to God as the subject of metaphysics. (3) He maintains that God's existence is shown only in metaphysics.

\section{AVERROËS}

Although Avicenna's account of the subject of metaphysics may seem to do full justice both to the requirements of Aristotelian science and to the nature of metaphysical inquiry, Averroës

9. Aristotle Posterior Analytics $1.28 .87 \mathrm{a} 38-87 \mathrm{~b} 4$.

10. Avicenna Metaph. 1.1.1 (4:6.8-15).

11. Avicenna Metaph. 1.1.2 (4:10.79-12.13).

12. Avicenna Metaph. 1.1.2 (4:12.14-22). The reader may wonder why Avicenna uses esse here in place of the more usual ens. Part of the answer seems to be that the ens considered by the metaphysician is the fact of existence. (For a discussion of this point, see Doig, Aquinas on Metaphysics, pp. 24-29). Whatever may be the doctrinal significance of using esse in place of ens, Avicenna tends to use the expressions esse inquantum esse and ens inquantum ens interchangeably. Compare Metaph 1.1.2 (4:12.28-32). 
considered Avicenna's position to be fundamentally flawed. Where Avicenna had gone wrong, according to Averroës, was in failing to see that the first alternative following on the hypothesis that God is not sought in metaphysics is true: God's existence is conceded for metaphysics and is established in another science, namely natural philosophy:

Accordingly, the consideration of forms belongs to two sciences. The first, natural science, discusses material forms; the second, which is the science of being as such, investigates the simple forms that are entirely separate from matter. But we should notice that the existence of this kind of being, namely, being separate from matter, is only discovered in this science, natural science. Moreover, anyone who contends that first philosophy tries to establish the existence of separate entities is mistaken. For such entities serve as the subject of first philosophy, and it has been stated in the Posterior Analytics that for a science to declare the existence of its subject is impossible. Instead, each science assumes that its subject exists either because the subject is evident in itself or because it has been demonstrated to exist in another science. Wherefore, Avicenna was gravely mistaken when he stated that the first philosopher demonstrates the existence of the First Principle and proceeded along these lines (which he deemed correct and even necessary) in his book On the Divine Science. Indeed, even the most certain of the arguments he employs in this book do not transcend the realm of probability. ${ }^{13}$

The elements of Averroës's solution to the problem posed by Avicenna are all contained in this text. Natural philosophy demonstrates the existence of separate entity through its proof that there must be an Unmoved Mover. Hence metaphysics does not need to show the existence of God or separate entity. Indeed, because, in Averroës's view, separate entity serves as the subject of metaphysics, metaphysics cannot show the existence of God and that for the very reason adduced by Avicenna-no science can prove the existence of its own subject.

What then is the subject of metaphysics for Averroës? In some texts, the question admits of a straightforward answer, but one easily

13. Averroës In Phys. Aristotelis 1 text 83, as in Opera Omnia 4 (Venice: Junta, 1550), fol. 22vb-23ra. Both from the context and the content of this passage, it is evident that Averroës intends to make a claim about the formal object of metaphysics, not just the material object. 
misunderstood. For Averroës will say that being as such is the subject, or rather that ens simpliciter is the subject. Yet what Averroës means by ens simpliciter needs to be carefully interpreted, as is evident in the passage given immediately above. Notice that, in discussing the second science that deals with forms, Averroës states that it is a science treating of "being as such" (de ente simpliciter) and "simple forms separate from matter." Within a few lines, however, Averroës also claims that the subject of metaphysics is separate entity. Would the Commentator be suggesting here that there are two (or more) subjects for metaphysics? Probably not. The key to interpreting these divergent statements lies in Averroës's interpretation of the focal meaning of being in Aristotle's Metaphysics. According to Averroës, just as things which are said to be healthy are referred to the primary instance of health found in animals for their meaning, so the nine accidents are referred to substance. ${ }^{14}$ Yet within substance there is an order of greater and less, according to priority and posteriority. Consequently, just as all things studied in natural philosophy have in their definition nature, so all things studied in metaphysics have in their definition God. ${ }^{15}$ Thus ultimately, for Averroës, the study of being as such means the study of the divine being, or God, and this is why he can claim that separate entities serve as the subject of first philosophy.

In sum, Averroës's theory of metaphysical knowledge is characterized by the following claims: (1) The primary and truly apodictic demonstration of God's existence is found in natural philosophy in the form of the proof for an Unmoved Mover. (2) The science of metaphysics formally depends on the demonstration of God's existence in natural philosophy, since metaphysics receives its subject through this demonstration. (3) Metaphysics is the science of being as being in that it is the study of being in its first instance, God or separate entity, and the study of secondary instances as related to God, insofar as God is First Form and Last End. ${ }^{16}$

14. Averroës In Metaph. Aristotelis 4 text 2, as in Opera Omnia 8, fol. 31r-v; and 4 text 7, fol. 31vb. On the focal meaning of being in Aristotle's metaphysical thought, see G. E. L. Owen, "Logic and Metaphysics in Some Earlier Works of Aristotle," in Aristotle and Plato in the Mid-Fourth Century, ed. Düring and Owen, Studia Graeca et Latina Gothoburgensia XI (Göteborg, 1960), pp. 163-190.

15. Averroës In Metaph. 6 text 2, fol. 69rb.

16. Averroës In Metaph. 4 text 6, fol. 294vK-L. 


\section{ALBERT THE GREAT}

Bearing in mind the Avicennian and Averroistic models of metaphysical knowledge, let us now turn to Albert's Physica and Metaphysica to determine which of the models he is more inclined to follow. We begin with the earlier Physica and then proceed to the Metaphysica as a way of checking for any change or development in Albert's position.

\section{ALBERT'S PHYSICA}

When Albert began to compose his Aristotelian commentaries around 1251, very little of Aristotle's philosophy had been expounded to the satisfaction of Latin readers. ${ }^{17}$ In embarking on his work as Aristotelian commentator, Albert intended to fill this lacuna both by presenting a literal exposition of the Stagirite's words and by interspersing his expositions with careful and thorough discussions, entitled digressiones, of the philosophical issues at stake. ${ }^{18}$ Albert

17. Albert Physica 1.1.1, ed. Paul Hossfeld, in Opera Omnia 4/1 (Munster: Aschendorff, 1987), p. 1, lines 9-14. Hossfeld dates Albert's composition of the Physica to c. 1251-1252 (p. vi). Since Albert taught theology at Paris before coming to Cologne, and so was more attuned to scholastic developments in Paris than elsewhere, it is not surprising to find him depicting the contemporary situation as one in which his brethren could not find a sufficient account of natural science. As a result of the proscriptions of Aristotle's writings promulgated in the early statutes of the University of Paris, very few commentaries on Aristotle's libri naturales were produced at Paris prior to the middle of the thirteenth century, after which the books of natural philosophy were included in the set of books to be read for university degrees: Nonetheless, one must remember that a considerable amount of valuable work had already been done on Aristotle's libri naturales at Oxford in the first half of the thirteenth century. Albert's statements about the lack of commentaries should not be taken as describing the entire Latin-speaking world. On the details of Albert's life and writings, see James A. Weisheipl, "Life and Works of St. Albert," in Albertus Magnus and the Sciences: Commemorative Essays, ed. Weisheipl (Toronto: PIMS, 1980), pp. 13-51. For the development of Aristotelianism at Paris, see Fernand Van Steenberghen, Aristotle in the West: The Origins of Latin Aristotelianism, trans. Leonard Johnston (Louvain: Nauwelaerts, 1970), pp. 89-138. The history of Oxford Aristotelianism is outlined briefly in the pioneering study of D. A. Callus, "The Introduction of Aristotelian Learning at Oxford," Proceedings of the British Academy 29 (1943): 229-281.

18. Albert Physica 1.1.1 (4:1.23-30). Despite Albert's obvious attempt to forward his own interpretation of Aristotle through the digressiones, there is some question of the extent to which one may legitimately read even the digressiones as Albert's own 
meant to make available, eventually, the whole of what he termed philosophia realis (comprising natural philosophy, mathematics, and metaphysics). He began, according to the order he thought best suited to learning, with natural philosophy and ended with metaphysics. ${ }^{19}$ Furthermore, from the very first of his Aristotelian commentaries, the Physica, Albert displayed the remarkable command of the newly translated Islamic and Jewish philosophical sources that made his commentaries popular in the thirteenth century and thereafter. In his Physica particularly, as the editor of the recently published critical edition has noted, ${ }^{20}$ Albert makes frequent use of Averroës's Commentarium, although he often disagrees sharply with Averroës's interpretation of Aristotle's Physics.

If we turn our attention to the end of Albert's commentary on Physica 1, where, as we saw above, Averroës most forcibly criticized the Avicennian schema of metaphysics, we discover that Albert has taken due note of Averroës's criticism and has prepared his own rejoinder:

There is another criticism that Averroës gives of Avicenna and this one is even less appropriate $<$ than the one just mentioned $>$. For Avicenna speaks the truth when he says that the same thing is not both sought in a science and presupposed in it, and that, since God and separate substances or forms are sought in first philosophy, they cannot, for that very reason, truly be presupposed in it and thus cannot be the subject of first philosophy. Furthermore, I have no idea why Averroës criticizes Avicenna, since what Avicenna says is necessarily the case. For we know that, since being is the subject of first philosophy, the divisions and properties of being are the matters treated in first philosophy, namely per se and per accidens, potency and act, unity and multiplicity, and separate and nonseparate. And, since

philosophy. In other passages, Albert claims that he is doing no more than stating the position of the Peripatetics. For an account of the significance of such passages, see James A. Weisheipl, "Albert's Disclaimers in the Aristotelian Paraphrases," in Proceedings of the Patristic, Mediaeval, and Renaissance Conference 5 (1982): 1-27. Although the issue of the extent to which the Aristotelian commentaries represent Albert's personal thought deserves further attention and study, its ultimate resolution is not required for the present paper, which only proposes to examine Albert's role as Aristotelian commentator.

19. Albert Physica 1.1.1 (4:3.29-41).

20. Paul Hossfeld, "Die Physik des Albertus Magnus (Teil I, die Bücher 1-4): Quellen und Charakter," Archivum Fratrum Praedicatorum 55 (1985): 52-53. 
separate is a difference and property of being, it cannot <itself> be the subject. Furthermore, when the metaphysician is said to be concerned with separate things, 'separate' is not understood in the manner in which the Intelligences are separate, but rather it is understood of those things that are separate in their definition and mode of existence. These, moreover, are the things which are considered in their simple quiddities, just as we stated in the foreword of this book. ${ }^{21}$

Several points should be noted in regard to this text. First, Albert's remarks are directly aimed at Averroës's Commentum 83 on the first book of the Physics and show unequivocally what Albert's general attitude is toward the disagreement between the two distinguished Islamic philosophers: Albert aligns himself with Avicenna. To state as much may seem to belabor the obvious, but the importance of doing so will be appreciated later when we encounter texts in which Albert uses language drawn from Averroës to express a doctrine rather different from that of the Commentator. Second, the reasoning that Albert gives for siding with Avicenna restates Avicenna's own reasoning but is made somewhat more precise through the introduction of the technical terminology of differentia and passio that is taken from the Posterior Analytics. 'Separate' cannot itself be the subject of a science, if it is shown to be the property of something else in that science. But this is precisely, Albert reasons, what happens in metaphysics. 'Separate' is demonstrated to be one of differences characteristic of being. The subject of metaphysics cannot, therefore, be a separate entity, whether the latter be identified with God, the Intelligences, or Separate Forms. Third, the notion of 'being' in the Albertian phrase 'being insofar as it is being' clearly does not carry the connotations associated with Averroës's phrase de ente simpliciter; the being with which the metaphysician deals does not signify primarily the separate entities. Lastly, there seem to be, by implication, two different meanings to the term 'separate'. 'Separate' denotes a difference and property of being, but 'separate' also describes a characteristic belonging to all the objects of metaphysical investigation. Yet no explanation of the latter is given in this text, and the reader is referred to the prooemium for further information.

21. Albert Physica 1.3.18 (4:76.37-56). Unfortunately, neither Zimmermann nor Doig seems to have known of this text, which provides the key to understanding Albert's whole position on the subject of metaphysics. 
Returning to the prooemium, we find the appropriate place in a section wherein Albert is discussing the three parts of philosophy and the formalities of their respective objects. Things are purely intelligible, Albert tells us, which are abstracted from motion and matter both according to their definition and mode of existence (secundum esse et diffinitionem). Those things which are abstracted from motion and matter only according to their definition and not their mode of existence are both imaginable and intelligible. Finally, those connected with matter and motion both in definition and mode of existence are sensible, imaginable, and intelligible. ${ }^{22}$ The objects so described, moreover, correspond respectively to the sciences of metaphysics, mathematics, and natural philosophy. ${ }^{23}$ Furthermore, Albert gives substance as an example of an object that is purely intelligible, describing it in terms similar to those found in the text quoted above: "For if the definition of substance insofar as it is substance is given, it will be one abstracting from all magnitude and all sensible things. And, for that reason, its definition will be given through simple quiddities which are grasped by the intellect."24 Added to what Albert has said elsewhere, this text implies that the intellect reaches a level of understanding at which it grasps what substance and other metaphysical notions are without adverting to the objects of sense or imagination. To be abstract in this manner belongs to the object apart from the mind's consideration (secundum esse et diffinitionem), yet clearly abstractness in this sense is not identified with the mode of existence belonging to God, angels, or separate souls. Instead, what abstract means in this context is that a given object is independent from matter and motion at least inasmuch as it instantiates such a notion as substance, since substance as such need not be in matter, ${ }^{25}$ although in the instance of a physical thing it is in fact found in matter. Indeed, as we will see shortly, and as

22. Albert Physica 1.1.1 (4:2.51-59).

23. Albert Physica 1.1.1 (4:1.49-60). On the various ordines of the sciences in the thirteenth century, see Robert Kilwardby, De ortu scientiarum 63, ed. Albert G. Judy, Auctores Britannici Medii Aevi 4 (Toronto: PIMS, for the British Academy, 1976), lines 214-219.

24. Albert Physica 1.1.1 (4:2.59-63).

25. Albert Physica 1.1.1 (4:1.60-67). 
Dähnert noted, ${ }^{26}$ Albert tends to call objects of this metaphysical sort 'divine' and even refers to them as the immediate outpouring of God.

Nonetheless, a hermeneutical difficulty would seem to obtrude itself at this point, because Albert does not use 'separate' in the texts just discussed but, rather, 'abstract' or 'abstracted'. Fortunately, Albert himself connects 'separate' and 'abstract' while explaining in what sense the objects of natural philosophy are sufficiently stable and mobile to serve as objects of scientific knowledge:

To understand this point, it is necessary to know that the things which are abstract or separate are abstracted in two modes, namely through their definitive nature-just as was said above-when the defining notes do not involve motion and sensibile matter, but are prior to these according to nature. And such a type of abstraction is found in nothing belonging to physics, whether the physical be taken as a subject or as a property proved to belong to a subject. There is, moreover, abstraction of the universal from this particular signate thing, such as occurs when we consider wood according to its nature and own mode of existence and not insofar as it is this wood, which is this cedar or this palm. And this type of abstraction is necessarily found in every science, since all science is concerned with the universal. 27

In the first of the two modes of abstraction mentioned by Albert, the things abstracted are said to be such in their own nature which is understood to be prior to both motion and sensible matter. Such a mode of abstraction, moreover, is said to be outside the realm of physics. Clearly, what Albert intends by abstraction here is precisely what he means by abstract in the text quoted immediately above, except that here he explicitly connects abstraction with separation. Hence, we are justified in using both the latter texts to illuminate Albert's description at the end of the first book of the Physica in which he hinted that there were two senses of 'separate' in metaphysics, one a property and difference of being and another a characteristic belonging to all metaphysical objects. Furthermore, the texts on abstractness and separation in the prooemium of Albert's Physica give

26. Ulrich Dähnert, Die Erkenntnislehre des Albertus Magnus: Gemessen an den Stufen der Abstractio (Leipzig: S. Hirzel, 1934), p. 126, especially n. 51.

27. Albert Physica 1.1.2 (4:5.1-14). Note especially the phrase "ea quae abstrahuntur sive separantur." 
us an insight into what he means by separate as a characteristic of all metaphysical objects. He teaches that in understanding any object metaphysically, the mind must grasp it without reference to, and apart from, matter and motion. Why? Because the object in its metaphysical nature transcends matter and motion - the object instantiates features that have nothing to do with, and are intelligible apart from, matter and motion. But to claim the latter is surely not to claim that a being or beings exist tout court apart from matter and motion, let alone to prove it. The latter, however, is exactly what is meant in metaphysics when separatum is used as a difference and property of being. Accordingly, Albert carefully distinguishes between the two senses of separatum, thereby implying that the origin of Averroës's mistaken analysis of the subject of metaphysics lies in his failure to make such a distinction.

If we summarize what we have learned from Albert's Physica regarding his position on the subject of metaphysics and the place within metaphysics for proofs for God's existence, we can state the following. First, with Avicenna, Albert explicitly argues that the existence of separate entity is proved in metaphysics and nowhere else. Second, Albert identifies the being of which the metaphysician treats not with the separate entities but in a manner similar to that of Avicenna. Accordingly, we may conclude that Albert's position in the Physica on the subject of metaphysics owes much more to Avicenna than to Averroës. Let us now turn our attention to Albert's Metaphysica, written some fifteen years later.

\section{ALBERT'S METAPHYSICA}

After a prooemium in his Metaphysica similar to that found in the Physica, Albert raises the question of what the subject of metaphysics is. He lists three opinions: one opinion according to which the ultimate causes are the subject; a second, according to which God and divine things are the subject; and a third, according to which being insofar as it is being is the subject. Clearly enough, this list of candidates for the subject of metaphysics derives from Avicenna's De prima philosophia, ${ }^{28}$ but so too do many of Albert's

28. Compare Avicenna Metaph. 1.1.1, which also lists the same three possible subjects for metaphysics. 
reasons for accepting the last candidate, being insofar as it is being, and rejecting the other two. What perhaps is more immediate to our purpose, however, is Albert's reasoning for rejecting the second opinion, for this, as we saw above, is the opinion of Averroës:

That this opinion is mistaken is evident through this <argument>. No selfsame thing is both the subject and something sought in a science. God and separate divine things are sought in this science. Therefore, they cannot be the subject of this science.

Furthermore, the parts of many things which are proved in this science are not reducible to God as to something commonly predicated of them, whether community be taken in the sense of a genus or in the sense of analogy.

The properties, moreover, considered in this science, which were ennumerated above, do not follow immediately upon God and divine things. Therefore, God cannot be the subject of this science. ${ }^{29}$

Albert shows no sign here of changing his mind regarding the opinion that God or separate entities are the subject of metaphysics, although he does not mention Averroës's name in connection with this opinion as in the Physica. Instead, Albert seems to have elaborated even more thoroughly his reasons for rejecting such an opinion by reducing his objections to two tersely stated syllogisms and an enthymeme. Each of these syllogistic arguments, moreover, points out a respect in which metaphysics would fail to meet the criteria of scientific knowledge laid down in the Posterior Analytics, if God or separate entities were posited as its subject. The first argument shows that if God were the subject, metaphysics would be a science in which the same thing is presupposed and proved. The second claims that if God were the subject, metaphysics would have no common predicate in its demonstrative syllogisms, contrary to the Aristotelian canon of dici de omni. The third indicates that if God were the subject of metaphysics, the Aristotelian rules of dici per se and dici de primo would be broken, since many of the properties demonstrated in metaphysics do not follow immediately upon God or divine things. 30

29. Albert Metaphysica 1.1.2, ed. Bernard Geyer in Opera Omnia 16/1 (Münster: Aschendorff, 1960), p. 4, lines 38-50.

30. On the conditions for scientific knowledge, see Aristotle, Posterior Analytics 1.4.73a21-74a4. For Albert's account of these conditions, see his Posteriora Analytica 1.2.7-15, ed. Auguste Borgnet, in Opera Omnia (Paris: Vivès, 1890), pp. 36-59. 
But to provide evidence that Albert still rejects the opinion that God or separate entity is the subject of metaphysics in the Metaphysica is not, in itself, a sufficient indication of Albert's own position on the subject of metaphysics or what place proofs for God's existence occupy within his notion of metaphysical knowledge-although the passage quoted immediately above might be sufficient to indicate his continued dependence on Avicenna. For information on these matters, we must turn, instead, to Albert's positive descriptions of the subject of metaphysics and to his account of book lambda of Aristotle's Metaphysics.

Albert's ex professo solution to the question about the subject of the Metaphysica is quite similar to the description of metaphysics given at the end of the first book of his Physica. The true subject of metaphysics is said to be being insofar as it is being (ens inquantum est ens) and the things following upon being as such are claimed to be the properties (passiones) of being. The items listed as properties of being are cause and effect, substance and accident, potency and act, and, significantly, separate and nonseparate. ${ }^{31}$

Likewise, in the very first chapter of his Metaphysica, Albert contrasts metaphysics with the other speculative sciences in much the same way he does in his Physica. But in the course of doing so, Albert also gives us a brief account of the sense in which metaphysics is transcendent and divine:

This science is called transphysical because that which is a nature determined by quantity or contrariety is based upon the principles of simple being [esse simpliciter], which < principles> altogether transcend everything called physical. $<$ This science $>$ is called divine, moreover, because all such principles are divine and best and first, giving to all other things the fullness of their being. For the being [esse] which this science considers is not conceived as confined to this <thing > or that, but rather insofar as it is the first outpouring of God and the first created thing prior to which nothing else has been created.... Among the theoretical sciences, moreover, the divine science which we now are treating excels <others> in that it provides the basis for the subjects, principles, and properties of all the other sciences and is not based, in turn, on any other. And this <science> is the perfection of the divine intellect within us in that it is about objects of thought [speculationibus] which are not connected with 
the continuum and time but are simple, being pure from things such as these which overshadow the divine being [esse divinum] and firm in that they are the basis of others, yet are not based on others in turn. ${ }^{32}$

Despite the manifest similarity between this text and the Physica in regard to the transcendence of being, a new note is introduced here. The being treated by the metaphysician is identified with the first created thing of the Pseudo-Aristotelian Liber de causis and is described in Neoplatonic overtones as the immediate outpouring of God. Hence, although Albert also employs the phrase ens simpliciter derived from Averroës, the meaning of that phrase is not at all the same as the one intended by Averroës. The being studied in metaphysics does not refer primarily or absolutely to separate entity or God, but to the first creature of God, being. This being is simple so far as it is no way connected with time and the continuum, a clear parallel to Albert's contention in the Physica that the objects of metaphysical speculation universally have the characteristic of being separate in the sense of being intelligible apart from motion and magnitude.

Furthermore, the connection of simple being (esse simplex) to being insofar as it is being is expanded upon by Albert in a later section of the Metaphysica. Metaphysics is claimed to be about four things: being insofar as it is being and its parts; the things following upon being as such, namely, unity and multiplicity; physical and mathematical entities inasmuch as they have their source in the principles of simple being; things wholly separate and ubiquitous in their existence, such as God and the Intelligences. Moreover, metaphysics retains its unity as a science, despite the diversity of the different items with which it deals because it treats all the things ennumerated under one formality,

32. Albert Metaphysica 1.1.1 (16:2.88-3.25). On the notion of esse simplex, see Leo Sweeney, "The Meaning of Esse in Albert the Great's Texts on Creation in Summa de creaturis and Scripta super Sententias," in Albert the Great: Commemorative Essays, ed. Francis J. Kovach and Robert W. Shahan (Norman: University of Oklahoma Press, 1980), pp. 65-95; and Sweeney, “Are Plotinus and Albertus Magnus Neoplatonists?" in Graceful Reason: Essays in Ancient and Medieval Philosophy Presented to Joseph Owens, CSSR, ed. Lloyd P. Gerson, Papers in Mediaeval Studies 4 (Toronto: PIMS, 1983), pp. 177-202. Albert's notion of esse primum creatum has been thoroughly explored in two other studies by Sweeney, "Esse primum creatum in Albert the Great's Liber de causis et de processu universitatis," Thomist 44 (1980): 599-646; and "A Controversial Text on esse primum creatum in Albert the Great's Liber de causis et processu universitatis," Proceedings of the Patristics, Medieval, and Renaissance Conference 5 (1982): 137-149. 
which is their having being not bound up with the continuum and time ("secundum esse non conceptum cum continuo et tempore"). ${ }^{33}$

What do these texts tell us about Albert's conception of metaphysical knowledge in the Metaphysica? As in his Physica, Albert maintains that the subject of metaphysics is being insofar as it is being (ens inquantum est ens), and he conceives being along Avicennian lines as something common, although his conception of being is much more indebted to Neoplatonic sources such as the Liber de causis than to Avicenna. ${ }^{34}$ Furthermore, in the midst of Albert's descriptions of the subject and scope of metaphysics, we once again seem to encounter two different senses of 'separate'. The first, here equated with esse simplex, is a characteristic belonging to all objects of metaphysical speculation precisely because of their independence from material conditions such as time and the continuum. The other is a division or property of being instantiated only in some beings studied in metaphysics. The language of property (passio), moreover, hearkens back to the Posterior Analytics and reminds us that, just as Albert himself stated in the key text at the end of the first book of his Physica, separateness in the second sense must be demonstrated to be a property of being. In looking to Albert's commentary on book lambda of the Metaphysics, therefore, we would expect Albert to claim that metaphysics attains a distinctive knowledge of God as an ens separatum.

Do we find such a claim in Albert's account of book lambda? Certainly Doig could find no trace of one. He argued, partially on that basis, that Albert's scheme of metaphysical knowledge was Averroistic in its conception. Here, however, we must distinguish two issues. As has already been established, Albert's conception of metaphysical knowledge is sufficiently Avicennian to require that he attribute a unique knowledge of God to the metaphysician, a knowledge of God in some way consequent upon the metaphysician's unique subject matter and entirely distinct from any knowledge of God as First Mover in natural philosophy. Consequently, the first issue is whether Albert does claim that metaphysics attains to a knowledge of God

33. Albert Metaphysica 1.2.11 (16:28.61-90).

34. Ludger Honnefelder, "Der zweite Anfänge der Metaphysik: Voraussetzungen, Ansätze und Folgen der Wiederbegründung der Metaphysik im 13./14. Jahrhundert," in Philosophie im Mittelalter: Entwicklungslinien und Paradigmen, ed. Beckmann, Honnefelder, et al. (Hamburg: Felix Meiner, 1987), p. 172. 
independent of the vicissitudes of natural philosophy, a demonstration of God as causa essendi and not merely as causa motus. Yet another issue is at stake, and it is on this also that Doig based his interpretation of Albert's position on the subject of metaphysics. That issue is whether Albert, in fact, offers any such proof of God's existence in his account of book lambda. Although this second issue deserves consideration, its solution is not necessary for determining Albert's position on the place of proofs of God's existence in the scheme of metaphysical knowledge, since Albert may consistently claim that metaphysics demonstrates God to be the cause of being without himself giving such a demonstration in his commentary. In turning to Albert's commentary on book lambda, then, we shall seek to settle only the first issue, whether Albert claims that metaphysical knowledge of God is knowledge of God as a causa essendi.

After explaining that the whole focus of the inquiry in book lambda is on substance and the principles and causes of substance, Albert introduces Aristotle's threefold division of substance. The division, Albert tells us, proceeds by distinguishing two primary types and then distinguishing two subtypes. The primary division is into sensible substance and supersensible substance, but the former category is further subdivided into corruptible and incorruptible. In regard to this division of substance, the ultimate task of metaphysics is to show the relationship among these types of substances. Albert describes how metaphysics accomplishes that task:

And thus there are three <substances> in general: sensible, incorruptible, but mobile; sensible, corruptible, and mobile; supersensible, immobile, and separate; and we must discuss all of these according to the method and mode of this wisdom. For we shall show which is the immobile and separate <substance> and how it is the principle of mobile, incorruptible substance, and we shall show how immobile, separate substance is also the principle of sensible, corruptible, and mobile substance through the motion of incorruptible, sensible substance. And in this will be the end and fulfillment of this work which is called wisdom, since then we shall know completely true being in itself and in its parts and according to its own properties [passiones]. ${ }^{35}$

Here Albert claims that metaphysics must identify separate entity and then show the connections among the three types of substance.

35. Albert Metaphysica 11.1.3 (16:462.28-40). 
Showing the connections seems to amount to indicating how separate substance is the principle of both types of sensible substance. Furthermore, Albert's language indicates that he still considers a knowledge of separate entity to be an intimate part of metaphysics, for, as in the Physica, he uses the term passio to describe how the knowledge of separate entity fits into the scope of metaphysical knowledge. ${ }^{36}$

Yet one might attempt to argue that Albert's intention has changed from the earlier Physica to the commentary on book lambda, since the text given here from book lambda does not close off the possibility of an Averroistic reading. After all, Albert does not speak unreservedly of metaphysics demonstrating the existence of separate entity in the text I have quoted immediately above but, rather, of metaphysics' identifying separate entity ("quae est immobilis et separata"). Perhaps, then, what Albert has in mind is not a demonstration of separate entity at all, despite his use of passio. Perhaps all metaphysics does here is to identify more clearly the properties of God, whose existence has already been established through the proof of the Unmoved Mover, by showing how God is a principle of all other substances.

That such an Averroistic interpretation of Albert's commentary on book lambda is mistaken, however, can be readily seen from two other passages in which Albert takes pains to distinguish the metaphysician's knowledge of God from that of the natural philosopher. In the first passage, Albert comments on Aristotle's remark that it is incumbent upon the metaphysician to ascertain the elements of incorruptible, mobile substance (at 1069a32-33):

For although in the physical <treatises > the elements of mobile substance have been taken up <for discussion>, nonetheless these elements have been understood of substance as mobile, not of substance as substance. But here we shall take up the elements of $<$ mobile $>$ substance so far as it is substance flowing from the First Formal $<$ Principle $>$ and Ultimate End; for this wisdom properly considers these causes. In the physical <treatises $>$, moreover, we considered both matter and efficient <causality>, and if we also spoke of form this was only of the form of the mobile and the end insofar as end is a term of the motion of a mover. Here, however, we shall show that the First and per se Efficient <Cause> is the Universal End and that from him flow all mobile substances and that he bears the

36. On Albert's use of passio to describe how separate entity is included under the subject of metaphysics, see above, note 22 . 
same relationship to the remainder of the universe that a general does to his army. For this <way of argument> is proper to this science and in this way we shall not at all be indebted to natural philosophy. Indeed, although we showed there through <a study of > motion that the First Mover is Unmovable, nonetheless we have not made clear that he is the Cause of all being [universi esse] both as a Form and as an End, and in this way we shall investigate the First Mover here. ${ }^{37}$

Likewise, in response to Averroës's argument that metaphysics only considers formal and final causes, Albert states:

Nor should we say, as certain people do, that the philosopher of nature considers <only> efficient and material causes and the metaphysician formal and final causes. Because, although we have already shown in the third book of this wisdom that the first philosopher principally considers form and end (through which he demonstrates according to the proper mode of his wisdom, in that these causes especially give us scientific knowledge), nonetheless both the metaphysician and the natural philosopher consider all four causes. But the natural philosopher considers these <causes> insofar as they are the principles of mobile <substance>, whereas the metaphysician traces back [reducit] efficient <causality> into the First Form and Last End; and in this way $\mathrm{He}$ is the Cause of all being [universi esse] both as a Form and as an End. Furthermore, if the First Cause is shown to exist [accipiatur] through motion, this is not so that he may be known as the Mover of such a motion, but rather insofar as he encompasses in his Power and Form both the mobile and motion, the former of which is $<$ but $>$ the instrument of the outflowing of all being from Him [fluxus totius entis $a b$ $i p s o]$. And in this way, the natural philosopher does not consider Him. ${ }^{38}$

Albert's intention in these texts is unambiguous. He wishes to distinguish the natural philosopher's knowledge of God from the metaphysician's. On what basis does he do so? Albert contends that the metaphysician, proceeding in the science of being as being, knows God as the cause of being (causa universi esse), and not simply as the cause of motion. Indeed, Albert elaborates the last point in the second text quoted so as to avoid all confusion; God may be known through motion but God is known in metaphysics not as Mover but as the Source of being. Motion simply serves as the means by which we know that God is the cause of being, just as, in the entitative order, 
motion serves as the instrument by which God communicates being to the universe. As expected, therefore, Albert does attribute a unique knowledge of God to the metaphysician in that Albert claims the metaphysician knows God to be the cause of being and not simply the cause of motion. Moreover, if we examine these texts for information regarding what type of proof or proofs a metaphysician would use to show the existence of God, they seem to require arguments in the orders of formal and final causality, but also, according to the second text, efficient causality. ${ }^{39}$ Yet to trace where or how Albert gives proofs of this sort would exceed, as was already pointed out, the scope and theme of this paper.

After considering all the pertinent texts, we must conclude that Albert's position on the subject of metaphysics is much more indebted to Avicenna than to Averroës. With Avicenna, Albert denies that God is the subject of metaphysics, contends that the subject of metaphysics is being insofar as it is being, and reserves the knowledge of God as the cause of being to the metaphysician. The texts in which Albert describes the metaphysician's knowledge of God, moreover, indicate that Albert believes there to be proofs for God's existence in the orders of efficient, formal, and final causality distinct from the proof of an Unmoved Mover in natural philosophy. Yet there is a certain tension unresolved in Albert's position on the subject of metaphysics, a tension first described by Zimmermann, but more recently studied by Thomassen and Honnefelder. ${ }^{40}$ Although Albert continues to use

39. Albert hinted in the Physica that the metaphysician would use efficient causality as one of the means by which to reach the First Cause. In commenting on the natural philosopher's use of efficient causality, he writes, "Et ideo omne principium physicum et omnem causam physicam accipit et colligit [sc. physicus], sed tamen non omnem causam efficientem nec omnem finem. Si enim acciperet omnem causam efficientem, oporteret, quod extenderet se ad aliquid non-physicum, quoniam prima causa est efficiens per essentiam suam, et de illa non intendit physica, sed prima philosophia. Eodem autem modo est de fine ultimo, qui est finis universitatis et est in prima causa sicut in duce exercitus." See Albert Physica 1.1.6 (4:9.60-69; emphasis mine).

40. Zimmermann, Ontologie oder Metaphysik? p. 155. Although his book is mainly devoted to studying how metaphysics fits into Albert's theory of human intellectual development, Thomassen makes some perceptive remarks. See Beroald Thomassen, Metaphysik als Lebensform: Untersuchungen zur Grundlegung der Metaphysik im Metaphysikkommentar Alberts des Grossen (Münster: Aschendorff, 1985), pp. 61-82, especially pp. 77-79. Examining the various conceptions of the subject of metaphysics 
the language of passio to describe how discussions of separate entity fit into metaphysics, he also claims that God and divine things are included under metaphysics as principles of the subject, as principles of being. ${ }^{41}$ Such language, anticipatory as it may be of Thomas Aquinas's position on the relationship of God to the subject of metaphysics, is rather difficult to relate to Albert's idea that 'separate' is a property of being. It is perhaps even more difficult to reconcile the language with Albert's notion that metaphysics has a single subject. For Albert never explains how discussions of God would fit into metaphysics, if God is taken up in metaphysics not only as 'separate entity' but also as the principle of the subject of the science. ${ }^{42}$ Nonetheless, despite troublesome passages indicating that Albert had other ideas on the subject of metaphysics which he never integrated into a coherent theory, the substance of Albert's views, as has been made clear from the present paper, derive from Avicenna.

St. Bonaventure University

throughout the High Middle Ages, Honnefelder traces the tension described here back to Aristotle, labeling it 'onto-theological'. See Honnefelder, "Der zweite Anfang der Metaphysik," pp. 164-167 and 171-177.

41. Albert Metaphysica 6.1.3 (16:305.75-306.4). See also note 33, above.

42. Indeed, in at least one place Albert shows his reluctance to confine God to any of the divisions of being which he usually gives by suggesting that antecedent to any of them is the division of being into ens a seipso and ens $a b$ alio. See Albert Metaphysica 1.4 .8 (16:57.62-79). 